\title{
CONTRIBUTION BETWEEN MULTIPLE CODEBTORS
}

\section{Fred T. HaNSON $\dagger$}

The common judicial proceeding of creditor against debtor, consisting of adjudication and enforcement as successive and in a measure independent steps, took its shape from the simple case involving one plaintiff and one defendant. A wholly satisfactory adaptation of this process to the final allocation of burden between codebtors, in those cases where there are three or more, has never been achieved.

Codebtors are usually liable in solido, so that the creditor may at his option pursue some one or more of the debtors, excluding others, until he obtains satisfaction. In the following pages some observations will be made concerning equalization of the incidence of burden among several coordinate debtors in the situations that frequently arise from the creditor's exercise of this right.

The doctrine of contribution, as it first emerged, established an aliquot part of the debt, computed according to the original number of debtors, as the maximum for which any one of them could be liable by way of contribution. $^{1}$ Where there were but two debtors this was not objectionable. But whenever there were three or more, one of whom paid the entire debt, that one alone bore the additional burden entailed if, for any reason, contribution was not or could not be enforced against some of the others. Today courts of equity and their modern successors, seeking a nearer approach to practical equality, agree that the rule must be qualified. In fixing the aliquot part for which a judgment of contribution may be had, they almost universally recognize that two classes of debtors may be omitted: insolvents and nonresidents. ${ }^{2}$ The effect of these doctrines has sometimes been stated in terms of the relationship which it implies between the codebtors themselves, quite aside from their conventional designation as either coprincipals or cosureties. Each is a principal debtor for his own aliquot part and a

†LL. B., I925, University of Nebraska; Judge, Red Willow County Court, Nebraska; contributor to various legal periodicals.

T. See Note, Proportion of Obligation Enforceable by Way of Contribution between Joint Obligors, subtitle At Common Law (1929) 64 A. L. R. 213, 228. Since the cases on the general subject dealt with herein are collected in the foregoing annotation and supplemental citations, no exhaustive review of authorities is attempted.

2. See subtitles Insolvency or Discharge of Part of Co-obligors, id. at 224, and Nonresidence or Absence of Part of Co-obligors, id. at 236 . The authorities generally indicate that in some states the paying debtor must seek a court of equity to secure the benefit of the modifications, and in others it will be given to him either in equity or at law. In New Hampshire, although there are no equity courts, the modified rule is nevertheless applied. Henderson $\mathrm{v}$. McDuffee, 5 N. H. 38 (I829). But in Georgia the adoption of the common law is held to carry with it the original rule, which precludes the omission of nonresident debtors in the calculation, although a statute authorizes the omission of insolvent cosureties. See comment upon Higdon v. Bell, 25 Ga. App. 54, 102 S. E. 546 (I920), infra note 8. 
surety for the balance. ${ }^{3}$ When there are more than two he bears a threefold relationship to each individual codebtor: principal as to his own share, surety as to the codebtor's share, and cosurety upon the remaining shares. ${ }^{4}$

The omission of insolvent debtors is justified upon the general ground that, so far as they are concerned, the usual presumption that what has been adjudicated can be enforced has failed. The loss to be anticipated ought not to be borne entirely by the one who first pays. ${ }^{5}$ The ground for the second omission is sometimes assimilated to that of the first on the theory that the nonresident is insolvent in terms of property within the jurisdiction of the forum. ${ }^{6}$ But, although he resides elsewhere, he may still have property within the jurisdiction which could be subjected to the claim. Even if he has no such property, ${ }^{7}$ it should be presumed that the sister state would afford effective process for collection from the nonresident in the absence of actual insolvency. ${ }^{8}$ Hence it is more realistic to place the omission of the nonresident on the ground that all domestic debtors should be made to share either the cost of foreign litigation or any loss that might follow a decision not to undertake it. ${ }^{9}$

The remedial operation of these modifications of the rule is exhausted when judgment is entered against the several debtors and the judicatory

3. Bragg v. Patterson, 85 Ala. 233, 4 So. 716 (I888) ; Norris v. Churchill, 20 Ind. App. 668,5 I N. E. I04 (I898); Greene v. Anderson, I02 Ky. 216, 43 S. W. I95 (I897); Goodall v. Wentworth, 20 Me. 322 (I84x) ; Henderson v. McDuffee, 5 N. H. 38 (I820); Baily's Estate, I56 Pa. 634, 27 Atl. 560 (1893); Liddell v. Wiswell, 59 Vt. 365, 8 Atl. 680 (I887); Wolford v. Bias, 79 W. Va. 349, 90 S. E. 875 (I9I6).

4. "Between themselves, each signer was a principal for the payment of one-ninth of the note, was surety to each other signer for one other ninth, and co-surety for the payment of the other seven-ninths. These relations the plaintiff had to each of the other signers." Liddell v. Wiswell, 59 Vt. $365,367,8$ Atl. 680 , 68I (I887).

5. The following passage from Keefer v. Valentine, I99 Iowa $1337,1342,203 \mathrm{~N}$. W. 787, 789 (1925), is a typical statement of this principle: "All others who are jointly bound with him and are solvent, not alone the one who pays, must bear their proportion of the loss resulting from the insolvency of one of them." (Italics supplied.)

6. "So far as regards the state of Kentucky, or the process of her courts, the nonresident is actually insolvent in property and irresponsible in person." Bosley v. Taylor and Thompson, 5 Dana 157,159 ( $\mathrm{Ky}$. I837). See also language quoted from Faurot v. Gates, 86 Wis. 569, 57 N. W. 294 (I893), infra note 27.

7. This was the situation in Johnson v. Tennessee Oil, Gas \& Mineral Development Co., 75 N. J. Eq. 314, 317, 73 Atl. 60, 62 (Ch. I909), where the court said: "The failure to find property within this state to satisfy the decree puts the complainant, so far as the courts of this state are concerned, in the same condition as if Reitlinger [nonresident debtor] were insolvent. . ."

8. Thus, in Higdon v. Bell, 25 Ga. App. 54, I02 S. E. 546 (1920), it was held that, in the absence of proof of actual insolvency, a nonresident cosurety could not be omitted under a statute providing that "If one of the cosureties be insolvent, the deficiency in his share must be borne equally by the solvent sureties." GA. CoDE (I926) $\$ 3564$. A dictum to the contrary in Hall v. Harris, 6 Ga. App. 822, 826, 65 S. E. 1086, ro88 (1909), was disapproved.

9. "We think the plaintiff . . . might well bring his action against the defendant in the manner he has done, and thereby throw upon the defendant the equal burden of going to the foreign jurisdiction, with the plaintiff, to seek contribution of the remaining cosigners, or of sustaining the loss without such effort, as he might choose. It would impose no greater hardship upon the defendant than the plaintiff. . . " Boardman v. Paige, Ir N. H. 43I, 440 (I840). ". . . the plaintiff is under no more duty to go into a foreign jurisdiction, and attempt to secure some indemnity from the estate of D. L. Dawley [an insolvent codebtor], than is the defendant." Liddell v. Wiswell, 59 Vt. $365,369,8$ Atl. 680, 682 (1887). 
step in the enforcement process is thereby closed. There are two factors, affecting the practical equality ultimately to be achieved, for which the exceptions do not provide: (I) A continuing liability of debtors who were omitted under the exceptions. ${ }^{10}$ This potential source of payment is not considered in the computation. (2) a. Debtors, thought and adjudged to be solvent when the aliquot parts were determined, who prove to have been or to have become insolvent under the practical test of execution. $b$. Debtors, resident at the time of judgment, who leave the jurisdiction with all their property before collection can be made. As potential sources of payment they thus become as unreliable or inconvenient of access as those that may have been, for similar reasons, left out of consideration.

Sums realized from omitted debtors have caused no serious concern. Their effect is adjustable by means of proper credits upon the several judgments. ${ }^{11}$ This is an administrative matter, incident to enforcement, which does not affect the adjudication itself. The same thing, in principle, is done whenever a creditor has judgments against some of several debtors liable in solido and a payment is made by another who may not even be a party to that particular action.

But when some of the resources counted upon in fixing the amount of each individual judgment are lost or impaired because of insolvencies or removals on the part of included debtors, the adjustment required is of a different kind. In order to meet the deficiency it would be necessary to increase the amount collectible from the sources remaining unimpaired.

Here the finality of the respective judgments presents an insurmountable obstacle. ${ }^{12}$ The amount remaining due on a judgment may readily be decreased by irregular credits, but it can in no event be increased. Yet the inequality from which the paying debtor suffers in these instances presents

10. "It goes without argument that the plaintiff has a clear right to contribution from each of the defendants, irrespective of their ability to pay. . . . To confine the judgment to one-nineteenth against each would defeat the rule of equity that the solvent members must bear the loss pro rata among themselves, where, subsequently to the rendering of such judgments, one or more of such judgment debtors should happen to become solvent and able to pay." Jewett v. Maytham, 64 Misc. 488, 492, Ir8 N. Y. Supp. 635, 638 (Sup. Ct. I909).

"If any of those liable to contribution were insolvent the liability of the others might be proportionately increased, but the insolvent would remain liable for contribution to those paying, and might be compelled to pay to them if he thereafter became able." Chalk v. Collier, 208 S. W. 972, 973 (Tex. Civ. App. I9I9).

"Provision must also be made for a resort to the future effects of such insolvent party; . . Brigden v. Cheever, ro Mass. 450, 455 (I8r3). See also Kimball v. Williams, 5 A App. Div. 616, 65 N. Y. Supp. 69 (4th Dep't, 1900), and Cranston v. Stanfield, I23 Ore. 3I4, 26I Pac. 52 (I927).

II. See extract from Jewett v. Maytham, 64 Misc. 488 , II8 N. Y. Supp. 635 (Sup. Ct. I909), cited infra note I5, and table infra note 16 , illustrating the effect of partial payments.

I2. "In case the judgments awarded the plaintiff are but for one-nineteenth of the entire amount against each defendant member, then, the judgment having fixed the amount of liability, it would probably be beyond the power of the court to increase the amount." Jewett v. Maytham, 64 Misc. 488, 492, II8 N. Y. Supp. 635, 638 (Sup. Ct. I909). "And while it would probably be convenient - . to have this amount in some way certified and found in the probate records, there could be no revision of it after the decree once fixed the sum of the liability." Rynearson v. Turner, 52 Mich. 7, II, I7 N. W. 219, 220 (I883). 
as strong an appeal for alleviation as that which is cured by the accepted modifications of the rule, within the sphere to which their operation is limited.

Comparison suggests that the principle by which provision is made for the first uncertain factor enumerated, followed through, would likewise afford a remedy for the second: in recognizing that the judgments against some of the codebtors may be increased to cover the shares of others, because collection from the latter is rendered, not impossible, but more than normally unlikely or onerous, the current rule in effect resolves the uncertainties wholly against the debtor whose liability is at issue. The ultimate adequacy and accessibility of any debtor as a potential source of payment is uncertain in some degree. This uncertainty also should, by parity of reasoning, be resolved against each debtor, resulting in a determination of his liability on the assumption that nothing more can be realized from other codebtors.

Whichever method is used, the resulting figure is inevitably provisional. It has often been observed that the doctrines of contribution are founded upon the general principle that equality is equity and not upon the agreement of the parties. The theory that the prospective contributor's responsibility for the shares of his codebtors is a general guaranty of ratable contribution, rather than of solvency only, is more in conformity with the principle out of which the whole doctrine arises. It does not follow that the codebtors' liability for contribution is joint. ${ }^{13}$ To the creditor each was liable for the others to the whole amount of their respective unpaid shares, whereas their liability to one of their own number who has paid the debt must, upon any theory, be something less than that. A judicial finding of solvency is virtually but a judicial prediction of collectibility which may prove wrong. In order to achieve equality in fact the actual results of operative legal process must, in one way or another, be made the criterion of the prospective contributor's proper burden. ${ }^{14}$ The manner in which such a plan would operate may be illustrated: An entire debt of $\$ 12,000$ has been paid by $P$, one of ten codebtors, designated as $A, B, C$ and so on. $P$ is entitled to judgment for $\$ 6,000$ against each of the others. $A$ pays $P \$ 6,000$, the amount of the judgment against him. Each of the others are now liable

I3. See infra note 25 .

I4. Trial courts have sometimes attempted equalization according to the actual effectiveness of executions against several debtors in the same judgment, where statutes give the paying codefendant the use of the joint judgment for the purpose of enforcing any rights against other codefendants arising by reason of the payment. But appellate courts have disapproved on the ground that the amount for which execution is allowed must be adjudicated in advance. Williams v. Riehl, I27 Cal. 365, 59 Pac. 762 (1899); Appleford v. Snake River Mining Co., I22 Wash. II, 210 Pac. 26, 29 A. L. R. 272 (I922). In the latter case the appellate court made this comment: "The trouble with this provision (of the decree below) is that there is no adjudication made by the court as to who is insolvent. This matter appears to be left to the plaintiff and the sheriff." Id. at 20, 210 Pac. at 29. Cf. Twichell v. Askew, I4I S. W. I072 (Tex. Civ. App. I9II); Key v. Oates, 280 S. W. 286 (Tex. Civ. App. 1926). 
for $\$ 4,000$ - one third of the debt-and if judgment had been entered against others, as it was against $A$, for $\$ 6,000$, appropriate credits should be given reducing the sums due to $\$ 4,000 .^{15}$ Like adjustments would be required as successive debtors contributed.

The manner in which the amount due from the respective debtors should be determined where partial contributions have been realized from several of them may be similarly shown: $P$ pays the entire $\$ 12,000$ and then realizes, by executions or voluntary payments, the following amounts- $A$ $\$ 3,45^{\circ} ; B \$ 3$, I5O; $C \$$ I,80o; $D$ and others nothing, making $P$ 's net contribution $\$ 3,600$. Each debtor is liable for the sum required to equalize the several contributions so far as may be without increasing his own payment beyond that of any debtor who participates therein. The amounts due from the several parties would be:

$A-\$ 75$ payable to $P$. The net contributions would then be $P \$ 3,525$; $A \$ 3,525 ; B \$ 3$, I $50 ; C \$ 1,800 ; D$ and others nothing.

$B-\$ 250$, of which the first $\$ 150$ should be paid to $P$ to equalize his contribution with that of $A$ at $\$ 3,450$, and the remaining $\$$ roo should be paid to $P$ and $A$ ratably to equalize their contributions with that of $B$ at $\$ 3,400$. If this were all paid $P$ would receive $\$ 200$ and $A \$ 50$, making the net contributions then stand- $P \$ 3,400 ; A \$ 3,400 ; B \$ 3,400 ; C \$ 1,800 ; D$ and others nothing.

$C-\$ 1,200$, the first $\$ 5$ o payable to $P$ as before; the next $\$ 600$ payable to $P$ and $A$ ratably to equalize their contributions with that of $B$ at $\$ 3$, I 50 ; and the remaining $\$ 450$ payable ratably to $P, A$ and $B$ to equalize their contributions with that of $C$ at $\$ 3,000$. If this were all paid $P$ would receive $\$ 600, A \$ 450$, and $B \$ 50$, making the net contributions then stand- $P \$ 3,000 ; A \$ 3,000 ; B \$ 3,000 ; C \$ 3,000 ; D$ and others nothing.

I5. In Jewett v. Maytham, 64 Misc. 488, II8 N. Y. Supp. 635 (Sup. Ct. 1909), a suit by two codebtors who had paid the debt against the remaining seventeen, all of whom were insolvent, the court said: "These considerations lead us to the conclusion that the plaintiff rightfully demands that he be placed in such a position by the decree to be rendered in this action that, in case any of the defendants shall in the future become solvent and possessed of property, the plaintiff may . . . compel contribution for full one-third of the amount paid to satisfy the . . judgments. . . It does not follow that the plaintiff would be entitled to collect the full amount of each several judgment so entered from each defendantdebtor as one after another may become solvent. The plaintiff is entitled to but one satisfaction of his just demand. But his just demand is not limited to one-third. . . . The plaintiff's real and just demand is to be repaid seventeen-nineteenths of that amount. If but one of the defendants should become solvent, the plaintiff would be forced to be content with the one-third of the amount actually paid; but in case, later on, a second defendant should be able to contribute, then he should be required so to do, and the three members of the association who had already paid the entire amount would have the right to call on the fourth solvent party to contribute a fourth, to be divided among the three who had previously contributed. It is thus apparent that each party who had contributed would have an interest in compelling each delinquent associate to also contribute. Each subsequent contributor lessens the burden of those who have already contributed. It is plain, therefore, if the plaintiff should succeed in collecting a judgment for one-third from any one of the defendants, that defendant should be equitably and proportionately subrogated, pro rata, to the plaintiff's right in the remaining unsatisfied judgments against the other defendants, as a means of compelling a proper contribution from each of them." Id. at 493 , IIS N. Y. Supp. at 638 . 
$D-\$ 2,550$, the first $\$ 50$ and the next $\$ 600$ payable as in the case of $C$, equalizing the contributions of $P$ and $A$ with that of $B$ at $\$ 3,150$; the remaining $\$ \mathrm{r}, 800$ payable ratably to $P, A$ and $B$ to equalize their contributions with that of $D$ at $\$ 2,55^{\circ}$. If $D$ 's liability, so determined, were paid in full $P$ would receive $\$ \mathrm{I}, 050, A \$ 900$ and $B \$ 600$, making the net contributions then stand-P $\$ 2,55^{\circ} ; A \$ 2,55^{\circ} ; B \$ 2,55^{\circ} ; C \$ 1,800 ; D \$ 2,55^{\circ}$; other debtors nothing. ${ }^{16}$

It should be observed that the illustrations contained in the four preceding paragraphs are alternative and not parallel in their application. As computation of the amount due from each is made on the hypothesis that nothing further will be paid by the other parties, payment by any one of them of all or any part of his liability alters the list of net contributions from which computations of present liability must be made.

However, simultaneous determination of the liabilities of the several parties may be required for the purpose of entering judgment. In a case where there had been partial payments from several sources and in varying amounts, a judgment against the parties for their several liabilities, ascertained as herein suggested, would be wholly unintelligible unless it also contained a finding and adjudication of the original amount of the debt and of the amount contributed by each of the debtors. In the cases to which refer-

I6. The illustrations contained in the four paragraphs of text immediately preceding this note are here given in tabular form, one column corresponding to each paragraph. Entire debt $\$ 12,000$ paid by $P$

Names of debtors

Amounts previously contributed

$$
(P-\$ 3,600 \text { net })
$$

Amount due from each on hypothesis that the others will pay nothing

Order in which sums are applied:

I. To payment of $P$

2. To payment of $P$ and $A$ ratably

3. To payment of $P, A$ and $B$ ratably

Total

Gross amount received by each distributee if liability paid in full :

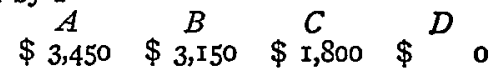

\begin{tabular}{|c|c|c|c|c|c|}
\hline \multicolumn{2}{|r|}{75} & & 250 & $\mathrm{r}, 200$ & 2,550 \\
\hline & 75 & & I5O & I50 & I50 \\
\hline & o & & 100 & 600 & 600 \\
\hline & 0 & & 0 & 450 & $I, 800$ \\
\hline$\$$ & 75 & $\$$ & 250 & $\$ \mathbf{I}, 200$ & $\$ 2,550$ \\
\hline
\end{tabular}

\section{Total}

The figures to the right in each column indicate what the net contribution of each of the parties would be if the liability of the party indicated at the head of that column were paid in full and distributed as indicated therein:

Total

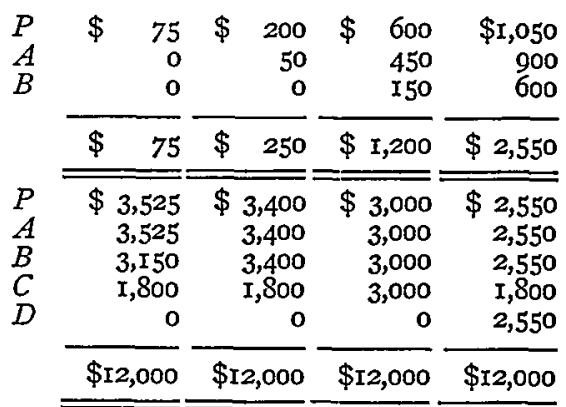

Incidentally, the foregoing table illustrates a transmutation of debtors into creditors, like that referred to in the extract quoted in the preceding note, except that here it results' from partial payments by several contributors. 
ence is made in the next paragraph it would also be necessary to determine the proportion of liability as between the several defendants in the action.

A group of codebtors, whether principals or sureties, may not be, as between themselves, primarily liable for equal amounts. ${ }^{17}$ In that event it is the respective proportions of contribution to primary liability, rather than the amount of the payments, which should be equalized to the extent possible. ${ }^{18}$ While the details differ, the general method of computation and administration will remain the same.

The equality attainable by exhausting the resources of each plan for enforcing contribution may be compared by an adaptation of the same hypothetical case: $P$, having paid the $\$ 12,000$ debt, desires to sue the nine codebtors for contribution. $D$ is a nonresident upon whom no service can be had, and at the time of judgment $E$ is provably insolvent. After judgment against the remaining seven, $F$ and $G$ move out of the jurisdiction and $H$ and $I$ become insolvent. $P$ has realized nothing from the parties mentioned above.

Supposing for the purpose of the illustration that any amount adjudged against $A, B$ and $C$ will be collected, and continuing to assume that nothing can be realized from the insolvents and that enforcement against the several nonresidents is impracticable, the several results, stated in terms of the ultimate cash contribution by each debtor, would be:

Original rule: $P \$ 8,400$. $A, B$ and $C$ each $\$ I, 200$.

Modified rule: $P \$ 7,500$. $A, B$ and $C$ each $\$ 1,500$.

Suggested rule: $P, A, B$ and $C$ each $\$ 3,000$.

Comparison in terms of the burden of litigation or other collection activity is similar in its broad outline only:

Original rule: $P$, the entire burden. Even if his efforts to collect are wholly successful, there is no approach to equalization of this burden.

Modified rule: $P$ making collection from $A, B$ and $C$. These three would share with $P$ efforts thereafter made to collect from the remaining debtors.

Suggested rule: $P$ making collection from $A . P$ and $A$ making collection from $B . P, A$ and $B$ making collection from $C .^{19}$

This burden evidently cannot be equalized perfectly, even between the solvent parties, by any convenient method. It may, indeed, be properly con-

17. "Primarily liable" is herein used in the sense indicated by the cases cited supra notes 3 and 4 and the text at that point.

I8. For proportion of contribution generally see Note, Proportion of Obligation Enforceable by $W a y$ of Contribution between Joint Obligors, subtitle Contribution According to Benefit, Interest, or Liability of Co-obligors (1929) 64 A. L. R. 213, 216. As an example of a case holding that contribution to cover the share of an insolvent should be in proportion to the contributor's "primary liability", and expressly repudiating the contention that this portion of the contribution should be equally according to the number of debtors, see Maresh v. Jennings, $38 \mathrm{~S}$. W. (2d) 406 (Tex. Civ. App. I93I).

19. This is upon the assumption that contribution will be forced from the debtors one by one, which involves the maximum of inequality. 
sidered as of secondary importance because of the general policy which leaves the expense of collection and litigation where it falls except to the extent that a remedy is afforded by statutes on costs or by contract provisions. Nevertheless, the omission of nonresidents under the current contribution rule plainly indicates that courts have thought this burden sufficiently important to require, in aggravated cases, a.doctrine that results in reallocation. ${ }^{20}$

While the situation of $P$, where he has but two codebtors, may differ little from that of a plaintiff in an ordinary case determined according to the general policy concerning expense of collection and litigation, his need for relief increases in direct proportion to the number of debtors until, as indicated in the illustrations, it may become even more urgent than that of the paying codebtor in a case involving fewer parties, some of whom are nonresident.

The suggestion that $P$ should recover half of the $\operatorname{debt}$ from $A$ has been repudiated as inequitable to $A$, who is not ultimately liable for so large a proportion. ${ }^{21}$ Even in the hypothetical situation here used for a comparison of the rules, $P, A, B$ and $C$ were at all times solvent residents, making $A$ 's liability at most one fourth.

The validity of this claim of inequality depends entirely upon the conception of $A$ 's obligation to $P$; whether this obligation of $A$ is (I) as one member of a group, whether consisting of all the codebtors, under the original rule, or of a reduced number ascertained in accordance with the current rule, or, (2) as an individual whose duty, as between himself and $P$, is to assume an equal share of the common burden. ${ }^{22}$

So the argument of inequality only leads back to the principal question. Under the latter view, even the suggested rule requires $P$ to be content with

20. See supra note 9. Decisions of collateral interest: United States Fidelity \& Guaranty Co. v. Naylor, 237 Fed. 314 (C. C. A. 8th, I916) (holding that the expense of the codebtors' "prudent and hopeful", though unsuccessful, defense of the creditor's suit should be included with the debt for purposes of contribution); Williams v. Riehl, I27 Cal. 365, 59 Pac. 762 (1899) (cosureties should share the burden of realizing upon collateral furnished to the paying surety by the principal debtor); Appleford v. Snake River Mining Co., I22 Wash. II, 2Io Pac. 26, 29 A. L. R. 268, 27 I (1922) (cosureties should share equally the burden of exhausting the principal's assets).

2I. In Lorimer v. Julius Knack Coal Co., 246 Mich. 214, 224 N. W. 362 (I929), there were fifty codebtors. The creditor first obtained a judgment against plaintiff and defendant, and later against one Sweeney. In reversing a judgment for the plaintiff, who had paid the creditor's judgment, against the defendant for one-half, on the theory that there were two codebtors in the first judgment, the court said: "The injustice that resulted to the defendant is obvious. It was compelled to bear one-half of the total burden instead of its proportionate share as between itself and the other original obligors. This is not at all in accord with the principle of equity and equality that underlies the doctrine of contribution. Even on the basis of judgment debtors, there were three of them, including C. F. Sweeney." Id. at 217, 224 N. W. at 363 .

In Owen v. McGehee, 6I Ala. 440 (I878), the court remarked that it is as unjust to compel a surety to bear more than his just proportion of the loss as it is to compel him to bear the whole burden, without contribution from his co-obligors.

22. See supra note 4. Cf. Boardman v. Paige, II N. H. 43I (I840), and Liddell v. Wiswell, 59 Vt. 365,8 Atl. 680 (I887), quoted supra note 9. 
something less than strict equality as between him and $A$, because $P$ had to find, in the first instance, the whole amount of the debt and had to assume the character of the sole moving party in the first step toward its reallocation.

Once $A$ has paid a moiety he is half owner of the contributions due from other debtors. If $B$ and $C$ in the illustration, who are still solvent, are not forced to contribute the amounts for which they are liable, and if contributions are not obtained from the remaining debtors to the extent that their solvency and accessibility will permit, half of the fault is $A$ 's. As between himself and $P$, there is certainly no inequality of which he can complain. It seems only fair that $P$ should be permitted to call on any of his colleagues, on whom he can conveniently bring pressure, to share with him the burden of the debt and of all further proceedings looking toward its proper ultimate allocation by way of contribution, ${ }^{23}$ as well as by way of reimbursement. ${ }^{24}$

To attain consistency in administering any theory of contribution between multiple codebtors would require, ideally, that all debtors be made parties to one proceeding, although their liability is certainly not joint. ${ }^{25}$ Indeed, this would be advantageous even where contribution according to the original aliquot parts is contemplated. In a separate action against one debtor the court would have to determine what persons were liable as codebtors in order to fix the amount of the judgment. Some of the supposed codebtors, not being bound by the judgment, might successfully defend suits against themselves. ${ }^{26}$ In that event the creditor would lose part of what he

23. Compare cases supra note 9.

24. Williams v. Riehl, I27 Cal. 365, 59 Pac. 762 (I899), and Appleford v. Snake River Mining Co., 122 Wash. II, 210 Pac. 26 (I922), quoted supra note 20.

25. A theory that the codebtors are jointly liable to the one who has paid for the aggregate of what the group ought to pay him would operate in one of two ways:

(I) To cause the risk of loss to pass from the first payer to the remaining debtors, thus: "[If] a recovery could be had against all four of those from whom he was entitled to contribution jointly, it might result in the original payee having to pay only one fifth of the whole amount, and yet three of his co-obligors who were solvent might finally be held liable for four fifths of the entire original obligation by reason of the insolvency of one of the joint obligors." Hall v. Harris, 6 Ga. App. 822, 826, 65 S. E. 1086, I088 (1909). Or, if the same process were repeated by each debtor as he was forced to contribute, the risk of loss would pass from one to the other until, in the above case, all of the loss from the insolvency of the fifth would have fallen on the fourth from whom collection was made.

(2) To produce the absurdity aptly described in Powell v. Matthis, 26 N. C. 83,87 (I843): "Indeed there is another consideration, which renders it perfectly clear, that a joint action can not be maintained; which is, that the plaintiff might thereon raise the whole recovery from one of the defendants, in the first instance, although the other might be solventwhich is wholly inadmissible. . - . For suppose three sureties A. B. and C. for a debt of $\$ 300$; and that $A$. pays it and then sues the other two for $\$ 200$. If $B$. then becomes insolvent and C. pays the judgment, he would then pay more than his proportion, and have a just claim on A.- to return to him $\$ 50$ to equalize their loss. But it is an absurdity, that one should recover in one action, what the defendant may have a right to recover back in another action; which shews that no action can be allowed, in which the recovery will not be confined to the sum for which the defendant is liable at all events." Cf. Brigden v. Cheever, to Mass. 449, 453, 454 (I8I3); Acers v. Curtis, 68 Tex. 423,4 S. W. 55I (I887).

26. "In this Court, the plaintiff, in order to show what is due from the devisee sued in one action, must show what is due from every other party liable to contribute. This is not only inconvenient, but may be hazardous, for the plaintiff; as the absent parties are not con- 
ought to have recovered in the first action. Lacking uniformity in the findings concerning the number of debtors, equality between the contributors could not be attained.

Under the modified rule, likewise, joinder is necessary to secure uniformity of denominator in the fractions determining the amounts due from the respective debtors. Where possible, insolvent debtors ought also to be made parties to the proceeding for the same reason. ${ }^{27}$ There is no recognized principle requiring enforcement against them, either by suit or by asserting a claim in liquidation proceedings, to be postponed until the solvent debtors have been made to pay, although the language of many of the decisions seems to imply that. ${ }^{28}$ Nor is there any principle that would justify fixing the amount due from an insolvent, as of any given time, at a different sum than would be deemed owing at the same time by a solvent debtor whose situation was otherwise identical. In this respect there is an anomaly inherent in the application of the modified rule. As the share of the insolvent is computed on the supposition that he may become solvent and able to pay, ${ }^{29}$ he is, hypothetically, included in the list of solvent debtors for the purpose of that computation. Consequently the denominator of the fraction representing his share must always be greater by one than in the fraction for which any one of the presently solvent codebtors in the same transaction would be found liable, and the amount of judgment against him correspondingly less. ${ }^{30}$ The legitimate effect of insolvency is that, in order

cluded by this judgment, and in a new action against either of them it may appear, from other evidence, that his share is less than is now supposed, when the plaintiff will lose the difference." Brigden v. Cheever, Io Mass. 449, 45I (1813).

That debtors not joined may, in a subsequent action, prove themselves not liable at all is taken into account in this passage from Rynearson v. Turner, 52 Mich. 7 , I7 N. W. 219 (I883): "The determination of the terms of contribution involved an inquiry into the liability and solvency of Turner, Tyler and Collar [codebtors] as well as of Lynn's estate [defendant]. . ." (Italics supplied.) Id. at II, I7 N. W. at 220.

27. Where one of three, who had agreed to pay in equal proportions, was insolvent, it was held that contribution between the two solvent parties should be by halves, with a provision in the decree enforcing contribution as to the insolvent party if he should thereafter be able to pay. Kimball v. Williams, 5I App. Div. 6I6, 65 N. Y. Supp. 69 (4th Dep't, I900).

". . the two insolvent debtors should not escape contribution entirely; they may eventualiy come into such financial condition that they can bear their portion of the burden . - .; judgment should be entered against them so that, in event it ever becomes collectible, execution may be had without resorting to another action or suit." Cranston v. Stanfield, I23 Ore. 3r4, 325, 26r Pac. 52, 55 (I927). See also Jewett v. Maytham, 64 Misc. 488, I I8 N. Y. Supp. 635 (Sup. Ct. I909), quoted supra note I5.

Following are two typical quotations from decisions to the contrary: "In chancery [in a suit for contribution], the insolvent principal and the insolvent sureties are not even necessary parties." Gross v. Davis, 87 Tenn. 226, 230, Ir S. W. 92, 93 (I889). "The insolvent and nonresident sureties are simply ignored. The nonresident is treated as an insolvent surety, and neither is a necessary party to a bill in equity for contribution; and so should it be, we think, in an action at law." Faurot v. Gates, 86 Wis. 569, 573, 57 N. W. 294, 295 (1893). cation.

28. All of the extracts given supra in notes 10 and 27 carry more or less of this impli-

20. See quotations supra notes io and 27.

30. Supposing for purposes of illustration that in Jewett v. Maytham, 64 Misc. 488, II8 N. Y. Supp. 635 (Sup. Ct. I909), only one of the two solvent debtors had paid the debt and then sued the remaining eighteen, he would have had judgment against the one solvent co- 
to produce equality when the estate of an insolvent is in liquidation, pro rata dividends are all that may be paid upon the amount which, if solvent, the debtor could at that time be compelled to pay in full. ${ }^{31}$ A construction, whereby the debt which will constitute a mere dividend base is itself reduced by the supervention of insolvency, necessarily makes the distribution to the owner of the claim less than a ratable share.

If the amount due from each debtor were to be computed upon the hypothesis advocated herein, that none of the others would make any further payments, the foregoing reason for joinder of all parties would not exist, but a collective proceeding would still be desirable for a different reason.

The problem of producing equality within a group, which is the objective here, suggests a technique like that used in liquidations. Because of the inefficacy or failure of collection processes in some instances, securing equality in the collection of a definite fund from several parties may, indeed, be a much more complex undertaking than ratable division of assets among a number of claimants. Provision for such contingencies, whether limited to proved insolvencies or not, may, in the course of administration, add a problem of equal distribution to earlier contributors of sums realized from later ones. ${ }^{32}$ In such a situation, where there may not only be several debtors, but several creditors as well, the separate enforcement of each individual creditor's rights against each individual debtor would be intolerable. ${ }^{33}$ Separate action against each debtor, without any diversity of creditors, is regarded as producing an objectionable multiplicity of suits. ${ }^{34}$

debtor for one half, according to the common application of the modified rule to cases where only the solvent parties are joined. But, the assumption under that rule being that whatever is adjudged against solvent parties will be collected in full, judgment against each of the seventeen insolvents would have been for no more than one third, just as it was in the actual case, where the two solvent debtors had already contributed equally to the payment of the debt.

Indeed, some decisions under the modified rule seem to assert that there is an even greater discrepancy between the liability of solvent and insolvent, by assuming that one of several insolvent codebtors is nevertheless liable for no more than an aliquot part according to the whole original number of debtors. Hinn v. Forbes, 264 S. W. I90 (Tex. Civ. App. I924).

3I. The basis on which an insolvent's estate should pay dividends in respect of a common debt is discussed in Hanson, Insolvency-The Codebtor as a Factor in Distribution (1937) 35 MICH. L. Rev. I099, IIIT.

32. The manner in which this necessity for redistribution is brought about is described in detail in the extract from Jewett v. Maytham, 64 Misc. 488 , II8 N. Y. Supp. 635 (Sup. Ct. I909), and is also illustrated in the table, supra note 16 . More general references to the need for the flexibility of equity practice where adjustments between multiple codebtors are involved are found in the following cases: Brigden v. Cheever, Io Mass. 449 (1813); Cary v. Holmes, 82 Mass. 127 (I860) ; Powell v. Matthis, 26 N. C. 83 (I843); Cowell v. Edwards, I26 Eng. Reprint I275 (C. P. I800). Cf. Mills v. Hyde, 19 Vt. 59 (I846), where the stress is laid on the nature of the issues to be tried rather than on the method of administration.

33. The language of Hinn v. Forbes, 264 S. W. Igo (Tex. Civ. App. 1924), indicates that if two debtors respectively paid half of the debt, there being four insolvent debtors, one of whom was joined in the action, they would be entitled to separate judgments against the insolvent party to the action for one sixth of one half. See comment, silpra note 30 . While this case contemplates that the judgments should be entered in one suit, it suggests that the rights of the contributees are several to the same extent as the liabilities of the contributors.

34. In Hall v. Harris, $6 \mathrm{Ga}$. App. 822, $65 \mathrm{~S}$. E. I086 (1909), in rejecting the theory of joint liability set forth supra note 25 (1), which involved only diversity of defendants, the court said: "If a co-obligor who has paid off a joint debt could proceed against the remaining 
There is, of course, the practical consideration that a court cannot always obtain jurisdiction of all the parties. In an action in personam there is no means of securing even a limited jurisdiction over nonresident absentees. Insolvent parties may be in the hands of a liquidating court whose jurisdiction is exclusive. Nevertheless, as many parties as are available should be included in the proceeding in order to administer complete contributive relief. Whenever anything is realized from debtors who could not be joined, the proper effect upon the respective rights and liabilities of parties to the suit, according to the understood formula, may be secured by supplemental judgments or decrees, made upon the application of any party to the suit. ${ }^{35}$

While administration of the suggested theory of contribution might seem intricate in cases involving many debtors, the same complexity is likewise a concomitant of the current rule in many of its applications. Parties who have paid their contributions, computed upon the basis of the solvent resident debtors, are placed in the position of creditors as to any subsequent payments or dividends from nonresidents or insolvents, so that here, too, a situation may be produced where there are several creditors as well as several debtors. What is more significant, in those cases where all except the paying debtor are insolvent, as well as in every case where all the solvent debtors have contributed and enforcement against several insolvent ones is contemplated, the methods of fixing the amount of liability and administering the resulting judgments is necessarily the same. ${ }^{36}$ Thus the adoption of the current rule approves the practicability of the theory of contribution here advocated.

The only alternative to some form of qualified responsibility for the shares of codebtors is adherence to the original rule, dismissing the paying

co-obligors and obtain a single judgment against all of them jointly, one of them might be compelled to pay the enire amount, and then he would have to proceed anew against the remaining co-obligors, and thus a multiplicity of suits would be encouraged, rather than prevented." Id. at $826,65 \mathrm{~S}$. E. at 1088. Indeed, a serious multiplicity of suits may result, even under a doctrine of strict aliquot parts, if the number of debtors is large. Consider, for example, the situation of the paying debtor in Lorimer v. Julius Knack Coal Co., 246 Mich. 2I4, 224 N. W. 362 (I929), in which there were fifty codebtors, none of whom were proved to be insolvent.

35. The following are typical references to the function of supplemental decrees in the administration of matters of this kind: "And the court in equity may render its decree for the payment by the respective sureties of the amounts they owe, and retain jurisdiction of the case and render supplemental decrees until the entire amount which all the sureties were liable to contribute has been paid by the solvent sureties, or some of them." United States Fidelity \& Guaranty Co. v. Naylor, 237 Fed. 314, 322 (C. C. A. 8th, I916). "Ihe failure to find property within this state to satisfy the decree puts the complainant . . in the same condition as if Reitlinger [a codebtor] were insolvent, . . . and, as this situation has developed in an attempt to work out the decree for complainant's rights which was based on Reitlinger's appearance and answer and the absence of any suggestion of his insolvency, the remedy is to be found in a further decree." Johnson v. Tennessee Oil, Gas \& Mineral Development Co., 75 N. J. Eq. 3I4, 3I7, 73 Atl. 60, 62 (Ch. 1909).

36. The extract from Jewett v. Maytham, 64 Misc. 488, II8 N. Y. Supp. 635 (Sup. Ct. rgog), quoted supra note I5, is a complete exposition of the operation of the current rule in such situations. Cf. Hinn v. Forbes, 264 S. W. I90 (Tex. Civ. App. 1924), cited supra notes 30,33 . 
debtor's complaint of inequality with the remark that it is but a legal consequence of the codebtor relationship, which one must be deemed to have contemplated in entering into it. The only virtue of that solution is simplicity of application. It has been too thoroughly repudiated to receive serious consideration. But the point is that since a qualified responsibility of each debtor for the others must be recognized, its translation into a present judgment means that a provisional figure must inevitably be given the finality of res judicata. Whenever this is done, under the familiar adjudication-enforcement sequence, the tentative amount ought to be the maximum that could conceivably be needed to meet every contingency that is within the reason for adopting a provisional amount. Only by the application of such a principle can the pattern of the ordinary judicial proceeding meet the exigencies of enforcing practical equality of contribution between multiple codebtors. 